\title{
Do Animals Need Citizenship?
}

\author{
Author : W.A. Edmundson \\ Date : November 12, 2014 \\ Will Kymlicka and Sue Donaldson, Animals and the Frontiers of Citizenship, 34 Oxford J. Legal. Stud. 201 (2014).
}

The planet's population of wild nonhuman animals has declined by one-third over the past fifty years. Over that same period the human animal population has doubled. (Hereon, I will simply refer to "animals" and "humans.") The two numbers and the trends they represent are connected. Human activity accounts for much of the decline in wild populations. Non-wild animal numbers have grown, over the same period, but this is due largely to the trebling of meat consumption by humans. This is expected to double again by the year 2050 . Something like 56 billion animals are now slaughtered annually for human consumption. Ten of them, approximately, for each one of us; and the ratio is growing. The amount of animal suffering due to purposeful or knowing human conduct is staggering.

There are signs that humans are becoming more thoughtful about, and more sensitized to, the suffering and exploitation of animals. Animal welfare laws have become more common and have begun to address the conditions of animals in factory farms. Nevertheless, the larger picture is depressing: an "Eternal Treblinka" (Zoopolis, P. 2) whose moral and political superstructure remains largely unquestioned. Despite over a century and a half of campaigning, human advocates for better treatment of animals have rather little to show for their efforts.

In their 2011 book, Zoopolis: A Political Theory of Animal Rights (Oxford University Press), Sue Donaldson and Will Kymlicka recite these facts in prefacing their diagnosis of the impasse that animal-welfare activism finds itself in. Activism has made little headway because advocates of better treatment for animals have, for the most part, argued within three theoretical frameworks, which the authors call a "welfarist" approach, an "ecological approach," and a "basic rights" approach. Welfarism, as they define it, accepts the subordination of animal interests to human interest, and advocates "humane use" of animals within that framework. The ecological approach focusses not on individual creatures but on the ecosystem itself, and promotes the interests of animals only insofar as that is part of protecting the ecosystem. The basic rights approach extends the idea of inviolable human rights to animals. Unlike the first two frameworks, the basic rights approach regards animal interests not as subordinate but as fundamentally equal to those of humans. The authors accept the basic rights approach, but confess that despite decades of articulation it has found a foothold only among certain activists and academics. It has "virtually no resonance amongst the general public" and remains "a political non-starter" (Zoopolis, PP. 5-6), even though electorates have increasingly shown a degree of worry about the treatment of animals. Why? Or, as the authors put it:

Having acknowledged that animals are living beings whose suffering matters morally, why is it so hard to take the next step and acknowledge that animals have moral rights not to be used as means to human ends? (Zoopolis, P. 5.)

The authors note that selfishness (both individual and corporate), selective blindness, and cultural tradition are contributing factors, but they argue that the typical way in which animal rights theory has been framed is itself an important obstacle: it "focuses on the universal negative rights of animals, and says little about positive relational duties." (Zoopolis, P. 6.) Typical negative rights are the right not to be murdered, not to be raped, not to be experimented on, while a typical positive duty would be to render aid to someone who is in distress, and a typical relational duty would be a duty to support one's family and to stick up for one's friends. The nearly exclusive theoretical concentration on generic negative rights for animals stands in stark contrast to the human context, in which "the vast bulk of reasoning and moral theorizing concerns not [the] universal negative rights but rather the positive and 
relational obligations we have to other groups of humans." (Zoopolis, P. 6.) So, the authors propose, let's talk about positive and relational rights for animals. At first, this seems to be an odd prescription to be making. If a short list of negative rights for animals is a hard sell, one would expect that enlarging the list to include positive rights would be harder still.

But there is more to the authors' prescription than might first appear. They point out that many of the rights and duties humans owe each other arise out of relationships: parent and child, teacher and student, master and apprentice, and the typically asymmetrical dependency of latter on the former gives normative content to the positive duties-and correlative positive rights - that arise. (It might be misleading to call these relational rights and duties, rather than positional rights and duties, because all rights are in a sense relational.) The first step, to escape the impasse animal rights theory finds itself in, is to take account of the many different ways that humans and animals interact. From this wide variety, Donaldson and Kymlicka extract three salient, morally relevant categories. There are domestic animals, that we have bred to be dependent upon us and live amongst us, such as household pets. There are wild animals, who are capable of living apart from us and with whom we have little interaction unless we are animal ethologists, zoologists, or zookeepers. Finally, there are liminal animals, that live amongst us but do not normally associate with us, such as squirrels and feral cats. The authors propose to recast animal rights theory so that it is structured around these three categories.

The way they do it involves taking what one might call a political-philosophical turn or reorientation. Because domestic animals live among us and must for the most part continue to do so, they are to be treated as citizens, enjoying the same rights and duties as human citizens-adjusting of course for relevant differences in ability, just as we do for children and the severely cognitively handicapped. Wild animals species are to be treated as sovereign nations having rights to their territories. Liminal animals are to be treated as foreign visitors or resident aliens. All three categories are protected by certain universal negative rights; but integrated with these are "differentiated positive rights" (Zoopolis, P. 11) that largely track the three categories.

The article I like a lot, Animals and the Frontiers of Citizenship, is a sequel to the book, elaborating and defending their proposal of citizenship for domestic animals in the states in which they reside. I was most struck by the originality of the proposal to attribute duties to domestic animals, two duties in particular. One is a duty of civility, that is, to behave appropriately to social circumstances: oxen should tread carefully, dogs should not lunge, cats should not scratch upholstery. Another is a duty of contribution: oxen should pull, dogs should fetch the newspaper, and cats should, well ... the article does not answer every question one might raise. The importance of attributing duties is that it meets a plausible demand that citizenship be founded on a capacity to enter and honor reciprocal relationships of mutual accountability. Although animals are fully capable of misbehavior, there is resistance to thinking them capable of wrongdoing. The authors, in fact, are doubtful of applying the concepts of moral and legal culpability to animals. Some will raise a conceptual objection to the notion of a creature's genuinely bearing a duty for which she cannot be blamed for breaching. Nonetheless, domestic animals clearly have a "capacity for norm-responsive behavior" (P. 215), and by "developing new ways of engaging the subjectivity of these co-citizens, focusing less on the ability to articulate or understand propositions, and more on attending to their 'varied modes of doing, saying and being'," (PP. 207-08) there may be enough to get a sufficiently robust idea of reciprocity going, to satisfy political philosophers and others who conceive citizenship in those terms.

Do domestic animals need citizenship, and the responsibilities and rights that constitute it? In other words, wouldn't they do just as well or better if they were recognized merely as non-rightholding beneficiaries of a suitable list of positive and negative duties borne by humans? After all, it's hard enough to win over skeptics about animal rights; won't it be even harder to convince a them that domestic animals have citizenship rights they don't really need? But Kymlicka and Donaldson present a plausible and attractive picture of how we all might be better off-humans and domestic animals alike - if we lived together in a community united in citizenship.

Cite as: W.A. Edmundson, Do Animals Need Citizenship?, JOTWELL (November 12, 2014) (reviewing Will Kymlicka 
and Sue Donaldson, Animals and the Frontiers of Citizenship, 34 Oxford J. Legal. Stud. 201 (2014)), https://juris.jotwell.com/do-animals-need-citizenship/. 